\title{
Editorial
}

\section{Interview - The thinking of J. A. Samaranch $\mathrm{i}$ Torrelló}

\author{
Mª JOSÉ MARTÍNEZ-PATIÑO1', JOSÉ ANTONIO PÉREZ-TURPIN² \\ ${ }^{1}$ Faculty of Science Education and Sport, University of Vigo, Pontevedra, Spain \\ ${ }^{2}$ Faculty of Education, University of Alicante, Alicante, Spain
}

In order to keep the life and works of J.A. Samaranch alive in the memory of the Olympic section of the Journal of Human Sport and Exercise, the Editorial Committee has decided to recover a previously unpublished interview from the fieldwork of lecturer $\mathrm{M}^{\mathrm{a}}$ José Martinez-Patiño. The interview gives an insight into the thinking of our close friend on subjects which still continue to represent a model of Olympic thought today.

The following is a transcript of the interview:

Do you think that we can identify a particular piece of legislation or a regulation that has been especially important for the advancement of women in Olympic sport?

Well, I think the problem faced by women in sport, and in Olympic sport, as athletes or players, is being resolved, because there are almost as many women as men playing sports and taking part in major sporting events. The big problem is the participation of women in sports management. Here we do find there are very few women in the governing bodies, international and national federations and Olympic committees, even on the International Olympic Committee. So, if women are to get the chance to be members of these sports organisations, a number of things have to be made easier for them. For example, if an international federation has 20 or 24 board members, then two new positions could be created which must be taken up by women, elected but women nonetheless. For example, you know women's football is more and more popular nowadays, but there isn't a single woman member of FIFA or the Spanish Football Federation, and things can't go on like this.

Corresponding author. Faculty of Education. University of Alicante. Campus de Sant Vicent del Raspeig s/n. 03690. Alicante, Spain.

E-mail: jose.perez@ua.es

JOURNAL OF HUMAN SPORT \& EXERCISE ISSN 1988-5202

(c) Faculty of Education. University of Alicante

doi:10.4100/jhse.2011.62.17 
Mr. President, what is your opinion on the reforms that you started within the Olympic movement as president of the IOC, do you think they will carry on?

Let's see, I was the first one to...I presided the IOC when women took part for the first time in its history, in 1981, when a Venezuelan and a Finnish woman joined us, and nowadays there must about 14 women. But that's not enough.

From your point of view, which men and women have made especially significant contributions along the road to integration? Can we highlight any particular woman as an important sportsperson or management figure?

Well, Anita deFrantz is one woman who collaborated with me, she's from the U.S.A. and she's done a tremendous amount to ensure that women reach the place they deserve in sports management.

Can you remember any event, IOC congress or meeting which you feel was a turning point in favour of the advancement of women in sport?

Yes, for me the most important event was the IOC session held in May 1981. For the first time in 87 years, as the IOC was created in 1894, the first woman was elected as a member of IOC.

And has this steady progress continued at the same pace in all Olympic sports or can we highlight one which has pioneered the progress of women, Athletics perhaps?

It's difficult for me to answer that question now but, for example there's a particular discipline which has always included women, that being the International Association of Athletics Federations and there have also been women in swimming and gymnastics, the three major Olympic sports. However, there are still some sports in which women don't participate, but there are also some sports where there aren't any men, aren't there? We haven't accepted women's boxing and I believe and hope it won't be accepted in the future either, although it's starting to become a little... we're starting to see women's bouts. My personal opinion is that I don't think it's a sport for women, however there are other sports, such as synchronised swimming and rhythmic gymnastics, which are only for women.

As president of the IOC you have very commendably visited 200 countries. Would you like to mention any one in particular that has made a special contribution to women's sport?

Among the countries that have done the most to defend the interests of women in sport we should mention countries from Northern Europe such as Norway, Sweden and Finland, not only in sport but in all areas of life, even in politics, where sometimes there are more women in parliament than men. 


\section{How do you see the evolution of women's sport in Spain?}

There's very little participation in Spain, although great strides have been made. You have to remember that 30 or 40 years ago there was practically no women's sport. What we need to do in our country is to ensure women are represented in the national and regional federations. Initially this representation should be obligatory.

What do you think have been the main obstacles to the advancement of women in sport?

Well, sport has always been governed by men and men don't really understand when they're told to give up a position to be replaced by a woman, and they don't like it. That's why we don't intend to make anyone step down but rather to increase the number of members of Spanish governing bodies and federations and, for example, reserve these extra positions exclusively for women.

So you feel that the problems really lie with the sports institutions and managers and not with women's attitudes?

Yes indeed, I do think that. If women aren't given certain advantages, it'll be very difficult to break this vicious circle where men elect men.

However, women are present at all levels in the modern Olympic movement, aren't they: as sportswomen, technicians and managers?

That's true for the International Olympic Committee, although there aren't as many women as there should be.

I see.

The agreement we reached was that at least $20 \%$ of senior management positions should be in the hands of women, and this isn't the case.

Mr. President, what role do you think the media plays in promoting women's sport?

Well, perhaps the media could give more importance to this area. Remember that almost all sports journalists are men.

Indeed, there certainly are obstacles to overcome, aren't there? As President, you have made a major contribution since the day you took charge - when will you be satisfied with the goals reached?

I'll be satisfied when there is equal representation in all sports organisations, such as international and national federations and the national Olympic committees. 
And with regard to the level of professionalism of sportswomen compared with men, we've still got a long way to go, haven't we?

That's true and we have to take it step by step, but we have to take those first steps. If not, we're just throwing our hands in the air and getting nowhere, and I have always insisted that we have to open the doors to women in sport.

One last question Mr. President, in 2001, as you mentioned previously, the American Anita deFrantz was the first woman to be a candidate for the presidency of the IOC. If he were alive today, what would Coubertain have thought about seeing a woman opting for the presidency of the IOC?

We can't compare Coubertain's time with ours, it's totally different. Coubertain's always accused of..

\section{Not supporting women.}

Of believing that sport wasn't for women. But if you went back to those times, at the start of the last century, a lot of people certainly felt the same, but we're in the 21st century, not the 19th or the 20th, and women have the status they deserve in some countries and I believe we have to take some other countries into account bit by bit, but there are many countries where women are still treated as inferior beings both politically and socially. There's even one very rich country where women are not even allowed to drive and that's not acceptable.

You've been very helpful Mr. President and I won't bother you with any more questions. Thank you very much indeed.

Thank you very much.

All the best, Mr. President.

Many thanks to Victor for his assistance 